\title{
Phylogenetic Analysis of Bacillus anthracis Strains Isolated from Clinical and Environmental Samples in Andhra Pradesh
}

\author{
B. Gireesha ${ }^{1}$, Devalam Rani Prameela ${ }^{*}$ and Bollini Sreedevi ${ }^{2}$ \\ ${ }^{1}$ State Level Diagnostic Laboratory, Sri Venkateswara Veterinary University, Tirupati- Andhra Pradesh, INDIA \\ ${ }^{2}$ Department of Veterinary Microbiology, College of Veterinary Science, Sri Venkateswara Veterinary University, \\ Tirupati-Andhra Pradesh, INDIA \\ *Corresponding author: DR Prameela; E-mail: raniprameela.dr@gmail.com
}

Received: 19 Nov., 2020

Revised: 10 Jan., 2021

Accepted: 16 Jan., 2021

\begin{abstract}
Anthrax, caused by Bacillus anthracis, is a severe zoonosis with a great impact on animal and human health. In the present study, 15 out of 16 isolates from clinical ear piece and soil samples (16), 8,6 and one samples isolated respectively from bovine, sheep and goat were confirmed as Bacillus on amplification of rpoB gene, 22 isolates (ear piece13, soil-9) were PCR positive for PA gene of PXO and 10 isolates (ear piece) amplified CAP gene confirming Bacillus anthracis. Similarly, all 31 isolates (earpiece-15 and soil-16) were confirmed as Bacillus anthracis on amplifying rpoB gene and chromosomal Ba813 gene. On nucleotide analysis with genus specific $r p o B$ gene of earpiece and soil isolates shown $99-100 \%$ identity, whereas nucleotide analysis with species specific genes; $P A$ of PXO1, $C A P$ of PXO2, rpoB and chromosomal Ba813 gene shown 98-100\% identity with their respective reference strains of Genbank. On phylogenetic analysis, earpiece isolates and soil isolates from endemic districts of Andhra Pradesh shown close evolutionary relationship with each other. However, earpiece isolates of Sr6 (Accession No:MK310254) and N3 shared ancestral relation with global reference strains of USA (Accession No:CP012730) and Japan (Accession no: AP014833) respectively. Similarly soil isolate of VM9 also shared ancestral relation with global reference strain of Japan (Accession no: AP014833). This phylogenetic analysis deciphered that there is no strain variation among isolates of $B$. anthracis collected from different clinical and soil samples of different districts of Andhra Pradesh.
\end{abstract}

\section{HIGHLIGHTS}

(0 99 to $100 \%$ nucleotide identity with genus specific and $98-100 \%$ with species specific genes.

( Close evolutionary relationship between clinical and environmental isolates.

0 No strain variation among isolates.

Keywords: Bacillus anthracis, Phylogenetic analysis, Multiple nucleotide alignment, clinical earpiece, Environmental soil

Anthrax is a particularly dangerous zoonotic disease caused by an aerobic gram positive spore forming bacterial species i.e. Bacillus anthracis. Genetically Bacillus anthracis is closely related to Bacillus cereus and Bacillus thuringiensis is believed to have diverged from its Bacillus cereus ancestor due to the evolutionary acquisition of two virulence plasmids pXO1 and pXO2 (Keim et al., 2008). The protective antigen (PA) and capsular (CAP) genes located on these plasmids are used as molecular markers for the routine identification of Bacillus anthracis from its close relative, Bacillus cereus and Bacillus thuringiensis.
However, occurrence of Bacillus cereus and Bacillus thuringiensis with either or both of these plasmids pose challenges in unambiguous identification of the species (Maughan et al., 2011).

Analysis of 16SrDNA sequences of B.anthracis (Akanza et al., 2020) by canonical single nucleotide polymorphism

How to cite this article: Gireesha, B., Prameela, D.R. and Sreedevi, B. (2021). Phylogenetic analysis of Bacillus anthracis strains isolated from clinical and environmental samples in Andhra Pradesh. J. Anim. Res., 11(1): 111-118.

Source of Support: None; Conflict of Interest: None 
(canSNP) was useful in detection of sublineage of strains isolated during outbreaks from India. Similarly, whole genome SNP analysis (Akiko et al., 2019) of Bacillus anthracis genes using DNA libraries were clearly indicated the phylogenetic relationships. Further, it is difficult to differentiate by plasmid analysis because of plasmid transfer among the closest species.

Genes in the plasmid of Bacillus anthracis have been successfully expressed in other bacteria (Thwaite et al., 2002) and been reported in other bacillus species (Pannucci et al., 2002). It is important to note that PXO2 can be lost naturally. Due to the natural competence of Bacillus thuringiensis and Bacillus cerus, the horizontal transfer of plasmids has been reported.

Identification of Bacillus anthracis by PCR targeting only toxin encoding genes (Pxo1 or PXO2) may not accurately identify the Bacillus anthracis, because of the transfer of plasmid by horizontal gene transfer among closely related species (Kwan et al., 2003). All the Bacillus anthracis isolates may not contain the toxin encoding genes and there is a chance of natural loss of plasmids (Kwan et al., 2003; Vahedi et al., 2009). Hence, in the present study, targeting combination of Bacillus anthracis specific chromosomal markers (chromosomal Ba813 \& rpoB genes) along with toxin encoding genes (PA gene of pXO1 and CAP gene of pXO2) were used for specific identification of Bacillus anthracis and to understand the phylogenetic relationship of Bacillus anthracis isolates.

\section{MATERIALS AND METHODS}

A total of 81 clinical and soil samples were collected for the study. For genus specific detection 5 amplicons targeting $r р о B$ gene were synthesized from 5 ear piece and 4 soil sample isolates. Similarly, for species specific detection, 13 PCR amplicons of PA gene of pXO1 (from 13 ear piece and 9 soil isolates), 10 PCR amplicons of CAP gene of pXO2 (from 10 ear piece isolates), nine PCR amplicons of $r p o B$ gene (from 5 ear piece and 4 soil isolates) and 31 PCR amplicons of chromosomal Ba813 gene (15 ear piece and 16 soil isolates) were synthesized. The PCR amplicons synthesized were sent to Genei private limited, Bangalore for sequencing and detection of Bacillus anthracis at genus and species level.

\section{Multiple nucleotide alignment and Phylogenetic analysis}

Multiple sequence alignment of nucleotide sequences was carried out using Clustal X 2.1 program to know percent identity and divergence. Phylogenetic analysis of received sequences of isolates were compared with analogous sequences of other B.anthracis isolates showing highest percent query coverage retrieved from Genbank, NCBI data base from different geographical regions to know the ancestral relatedness and evolutionary relationship of the isolates (Table 1a-1e).

Table 1a: List of genus specific rроB gene nucleotide sequences retrieved from the Gen Bank for multiple nucleotide alignment and phylogenetic analysis

\begin{tabular}{lllll}
\hline $\begin{array}{l}\text { Sl. } \\
\text { No. }\end{array}$ & Strain & Country & $\begin{array}{l}\text { Accession } \\
\text { no. }\end{array}$ & Year \\
\hline 1 & SPV 842-15 & Brazil & CP019588 & 2017 \\
2 & MCCC 1A02161 China & CP031642 & 2018 \\
3 & Tyrol 4675 & Germany & CP018903 & 2017 \\
4 & Shikan-NIID & Japan & AP014833 & 2015 \\
5 & London-499 & London & CP029805 & 2018 \\
6 & DL7 & Maharastra, India & JN572676 & 2015 \\
7 & Parent-1 & USA & CP012730 & 2016 \\
8 & 34F2 & Uttar Pradesh, India JQ798178 & 2016 \\
9 & IVRIKOLBAI & West Bengal, India & KT831967 & 2016 \\
\hline
\end{tabular}

Table 1b: List of species specific $P A$ gene nucleotide sequences retrieved from the Gen Bank for multiple nucleotide alignment and phylogenetic analysis

\begin{tabular}{lllll}
\hline $\begin{array}{l}\text { Sl. } \\
\text { No. }\end{array}$ & Strain & Country & $\begin{array}{l}\text { Accession } \\
\text { no. }\end{array}$ & Year \\
\hline 1 & London499 & UK & CP029806 & 2018 \\
2 & SPV 842 & Brazil & CP019589 & 2017 \\
3 & Tyrol 4675 & Germany & CP018904 & 2017 \\
4 & Shikan-NIID & Japan & AP014834 & 2015 \\
5 & Canadian & USA & CP010321 & 2016 \\
6 & 34F2 & Uttar Pradesh, India & JQ798178 & 2016 \\
7 & IVRIKOLBAI & West Bengal, India & KT831967 & 2016 \\
\hline
\end{tabular}

A cladogram, based on partial sequences, was generated using the MEGA 6.0 program (Tamura et al., 2013) based on the Kimura-2-parameter model. The sequences were aligned in Clustal W, and phylogenetic trees were 
constructed using the Maximum Likelihood method. The robustness of the tree was assessed with 1000 bootstrap replicates and percent identity was performed to identify similarity and differences between analyzed sequences and also between analyzed and reference sequences.

Table 1c: List of species specific $C A P$ gene nucleotide sequences retrieved from the Gen Bank for multiple nucleotide alignment and phylogenetic analysis

\begin{tabular}{lllll}
\hline $\begin{array}{l}\text { SI. } \\
\text { No. }\end{array}$ & Strain & Country & $\begin{array}{l}\text { Accession } \\
\text { no. }\end{array}$ & Year \\
\hline 1 & London499 & UK & CP029807 & 2018 \\
2 & Tyrol 4675 & Germany & CP018905 & 2017 \\
3 & Shikan-NIID & Japan & AP014835 & 2015 \\
5 & Canadian & USA & CP010320 & 2016 \\
6 & IVRI-1975 & Uttar Pradesh, India & KM019143 & 2016 \\
7 & SVA11 & Sweden & CP006744 & 2016 \\
\hline
\end{tabular}

Table 1d: List of species specific rроB gene nucleotide sequences retrieved from the GenBank for multiple nucleotide alignment and phylogenetic analysis

\begin{tabular}{lllll}
\hline $\begin{array}{l}\text { Sl. } \\
\text { No. }\end{array}$ & Strain & Country & $\begin{array}{l}\text { Accession } \\
\text { no. }\end{array}$ & Year \\
\hline 1 & SPV 842-15 & Brazil & CP019588 & 2017 \\
2 & MCCC 1A02161 & China & CP031642 & 2018 \\
3 & Tyrol 4675 & Germany & CP018903 & 2017 \\
4 & Shikan-NIID & Japan & AP014833 & 2015 \\
5 & London-499 & London & CP029805 & 2018 \\
6 & DL7 & Maharastra, India & JN572676 & 2015 \\
7 & Parent-1 & USA & CP012730 & 2016 \\
\hline
\end{tabular}

Table 1e: List of Chromosomal Ba813 gene nucleotide sequences retrieved from the Gen Bank for multiple nucleotide alignment and phylogenetic analysis

\begin{tabular}{lllll}
\hline $\begin{array}{l}\text { SI. } \\
\text { No. }\end{array}$ & Strain & Country & $\begin{array}{l}\text { Accession } \\
\text { no. }\end{array}$ & Year \\
\hline 1 & SPV 842-15 & Brazil & CP019588 & 2017 \\
2 & MCCC 1A02161 & China & CP031642 & 2018 \\
3 & Tyrol 4675 & Germany & CP018903 & 2017 \\
4 & Shikan-NIID & Japan & AP014833 & 2015 \\
5 & London-499 & London & CP029805 & 2018 \\
6 & Parent-1 & USA & CP012730 & 2016 \\
\hline
\end{tabular}

Journal of Animal Research: v. 11, n. 1, February 2021

\section{RESULTS AND DISCUSSION}

Multiple nucleotide alignment of Bacillus isolates recovered from clinical earpiece and environmental soil samples

The results of Multiple nucleotide alignment of genus specific rpoB gene of Earpiece (Sr6) and soil isolates (SJ6, VV25) showed a nucleotide identity of $100 \%$ with reference gene bank strains of Brazil strain (Accession No: CP019588), Germany strain (Accession No:CP018903), London strain (Accession No: CP029805), USA strain (Accession No: CP012730). Multiple nucleotide alignment of species specific $P A$ gene of all the earpiece (13) and soil (9) isolates resulted in a nucleotide identity in the range of $98-99 \%$ with reference strains of Brazil (Accession No: CP019589), Germany (Accession No: CP018904), Japan (Accession no: AP014834), London (Accession No: CP029806), USA (Accession No: CP010321), Uttar Pradesh (Accession No: JQ798178) and West Bengal (Accession No: KT831967).

Similarly multiple nucleotide alignment of species specific CAP gene of NelloreN3 earpiece isolate showed 100\% nucleotide identity with ChittoorI15 earpiece isolate. Multiple nucleotide alignment of species specific rpo $B$ gene of NelloreN3 earpiece isolate showed a nucleotide identity with reference sequence of Japan strain (Accession no:AP014835), whereas AnnathapurAS30 showed 100\% nucleotide identity with KurnoolKN18 soil isolate.

Multiple alignment of Ba813 gene of I1, I14, K10, N3, N4, N7, Sr6 earpiece isolates and AS28, KN18, KN21, VG4, VP11, VP12, VV25 soil isolates showed a nucleotide identity of $100 \%$ with reference strains of Brazil (Accession No:CP019588), Germany (Accession No: CP018903), London (Accession No: CP029805) and USA (Accession No: CP012730). The results of multiple alignment of nucleotide of all the genes of remaining isolates showed a nucleotide identity in the range of 98$99 \%$ with their respective reference strains of Genbank.

Results of Phylogenetic analysis of Bacillus isolates recovered from clinical earpiece and environmental soil samples

Phylogenetic analysis of genus specific $r p o B$ gene of clinical earpiece isolates, $\mathrm{Sr} 6$ isolate showed close 
relationship with USA strain (Accession No: CP012730) and remaining other isolates $(\mathrm{N} 3, \mathrm{~K} 12, \mathrm{Ch} 8$ and $\mathrm{A} 5)$ formed separate clusters with reference strains Brazil strain (Accession No: CP019588), Germany strain (Accession No:CP018903), USA strain (Accession No: CP012730), London strain (Accession No:CP029805), China strain (Accession No:CP031642), Japan strain (Accession no: AP014833). But Sr6, N3, 1K12, Ch8 and A5 formed separate clusters with reference Maharastra strain (Accession No: JN572676). Whereas, Sr6, N3, K12, Ch8 and A5 formed separate clusters with each other (Fig. 1).

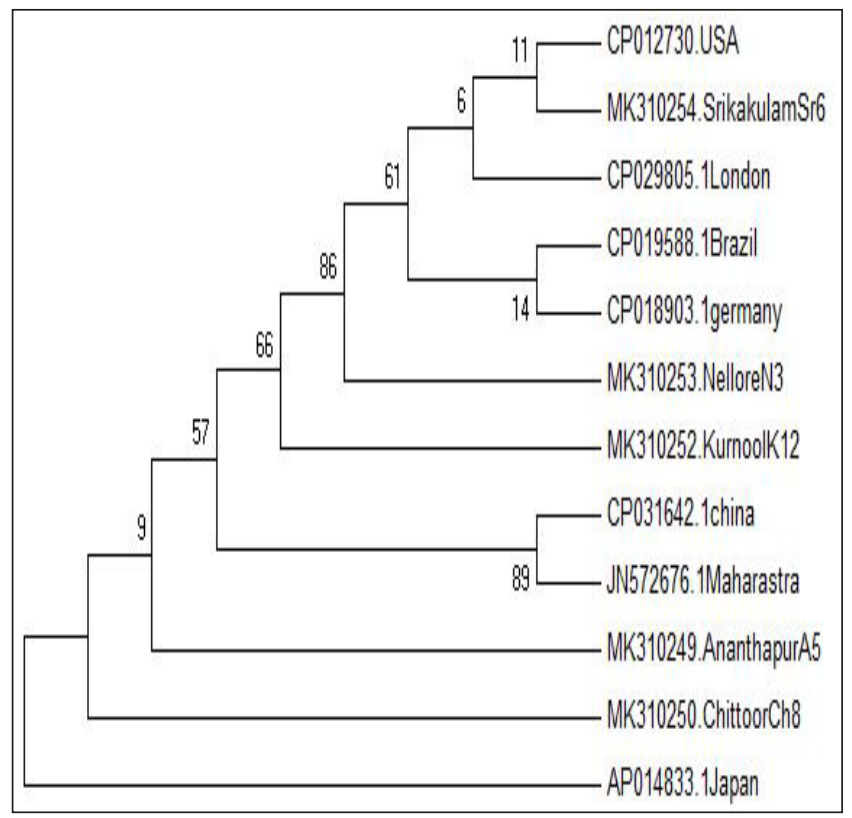

Fig. 1: Phylogenetic analysis of $r p o B$ gene (earpiece isolates) of Bacillus genus-Andhra Pradesh

Similarly, the phylogenetic analysis of genus specific rров gene of environmental soil isolates of SJ6, VV25, $\mathrm{KN} 18$, AS30 formed separate clusters with reference strains Brazil strain (Accession No: CP019588), Germany strain (Accession No:CP018903), USA strain (Accession No: CP012730), London strain (Accession No: CP029805), China strain (Accession No: CP031642), Japan strain (Accession no: AP014833). Whereas SJ6, VV25, KN18, AS30 formed separate clusters with Maharashtra strain (Accession No: JN572676). SJ6 isolate showed close relationship with VV25 isolate but $1 \mathrm{KN} 18$ and AS30 formed separate clusters with other isolates (Fig. 2).

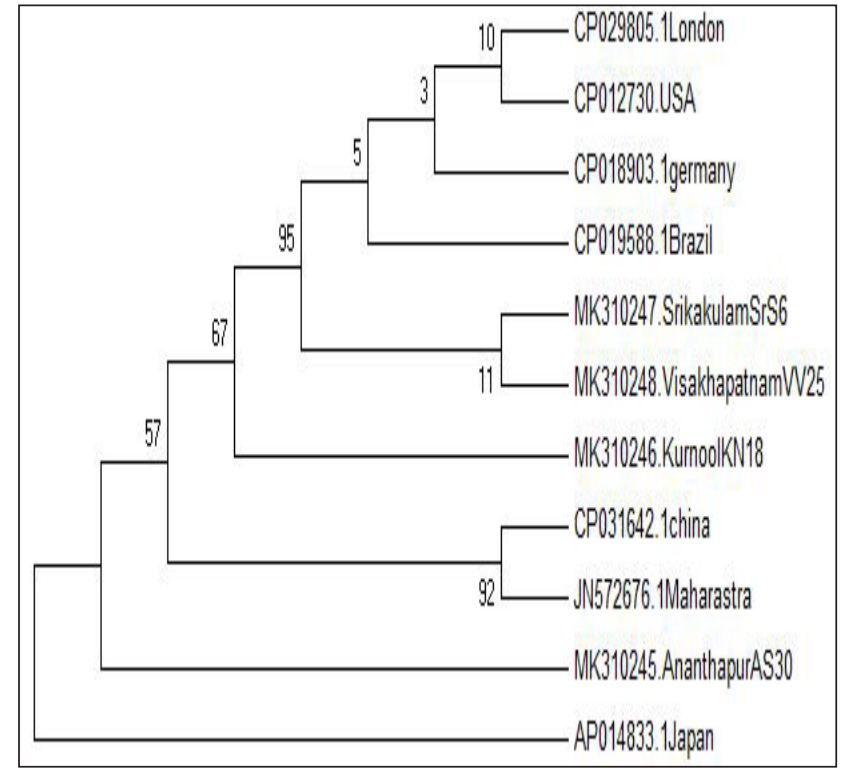

Fig. 2: Phylogenetic analysis of $r p o B$ gene (soil isolates) of Bacillus genus-Andhra Pradesh

Results of Phylogenetic analysis of Bacillus anthracis isolates recovered from clinical earpiece and environmental soil samples

The Phylogenetic analysis of $P A$ gene of earpiece isolates of I1, I2, N3, N4, A5, Sr6, N7, Ch8, I9, 1K10, Ch11, A13, I15 formed separate clusters with reference strains Brazil strain (Accession No: CP019589), Germany strain (Accession No: CP018904), Japan strain (Accession no:AP014834), London strain (Accession No:CP029806), USA strain (Accession No: CP010321). The isolates I1, I2, N3, N4, A5, Sr6, N7, Ch8, I9, 1K10, Ch11, A13,I15 formed separate clusters with reference Uttar Pradesh strain (Accession No: JQ798178) and West Bengal strain (Accession No: KT831967). But I9, I1, Ch8, K10 isolates showed close relationship with Ch11, I15, N7, Sr6 isolates respectively (Fig. 3).

Similarly, the Phylogenetic analysis of PA gene of soil isolates AS33, KN21, AS31, AS38, VM7, AS30, VM9, 1KN19, VV25 formed separate clusters reference strains Brazil strain (Accession No: CP019589), Germany strain (Accession No: CP018904), Japan strain (Accession no:AP014834), London strain(Accession No: CP029806),USA strain (Accession No: CP010321) of Gen bank. AS33, KN21, AS31, AS38, VM7, AS30, VM9, 
KN19, VV25 formed separate clusters with reference strains i.e. Uttar Pradesh strain (Accession No: JQ798178) and West Bengal strain (Accession No: KT831967). The isolates AS30, VM9 showed close relationship with KN19, VV25 respectively. But AS33, KN21, AS31, AS38, VM7 formed separate clusters with other isolates (Fig. 4).

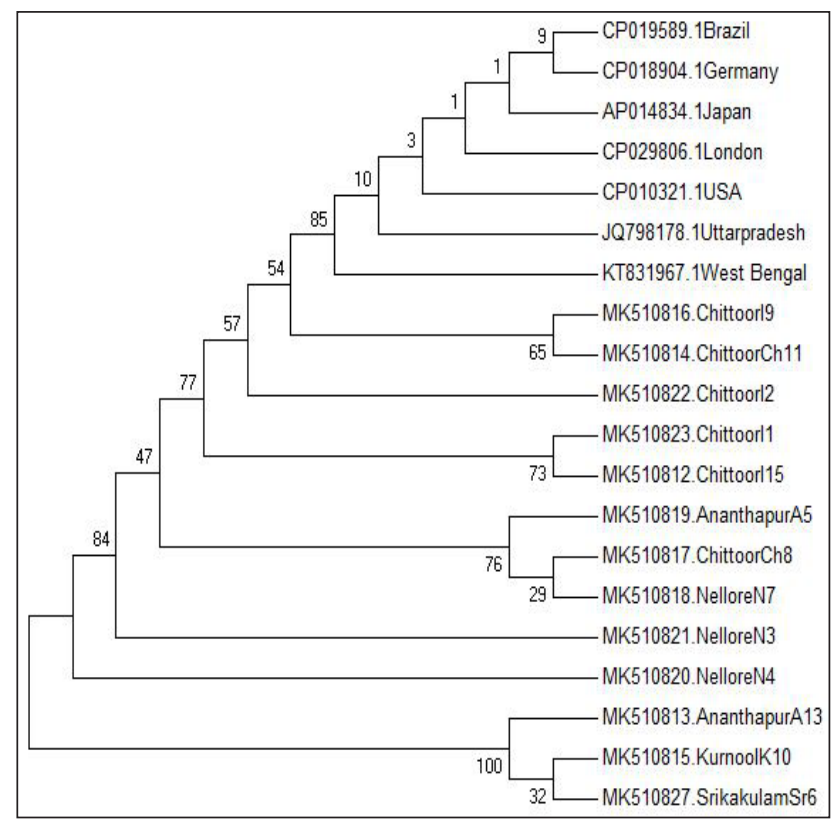

Fig. 3: Phylogenetic analysis of $P A$ gene (earpiece isolates) of Bacillus anthracis -Andhra Pradesh

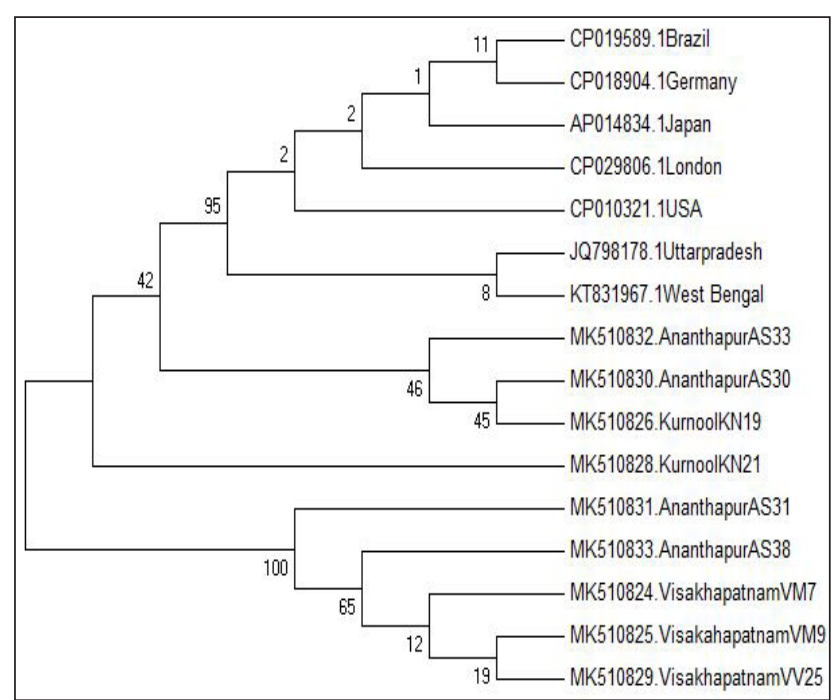

Fig. 4: Phylogenetic analysis of $P A$ gene (soil isolates) of Bacillus anthracis-Andhra Pradesh

Journal of Animal Research: v. 11, n. 1, February 2021
The Phylogenetic analysis of $C A P$ gene of earpiece isolates of K10, A5, I2 isolates formed separate clusters with N4, I15 isolates and London (Accession No: CP029807), Germany (Accession No:CP018905), Japan (Accession no: AP014835), Sweden (Accession No: CP006744) reference strains of genbank. Sr6, I1 isolates formed separate clusters with USA (Accession No: CP010320) strain. Sr6, I1 isolates formed separate clusters with Uttar Pradesh (Accession No:KM019143) strain. N3 isolate showed close relationship with Uttar Pradesh strain (Accession No: KM019143). I15, Ch11 showed close relationship with N4, Ch8 isolates and respectively. Sr6, I1 isolates formed separate clusters with $\mathrm{Ch} 8, \mathrm{Ch} 11, \mathrm{~N} 3$ isolates (Fig. 5).

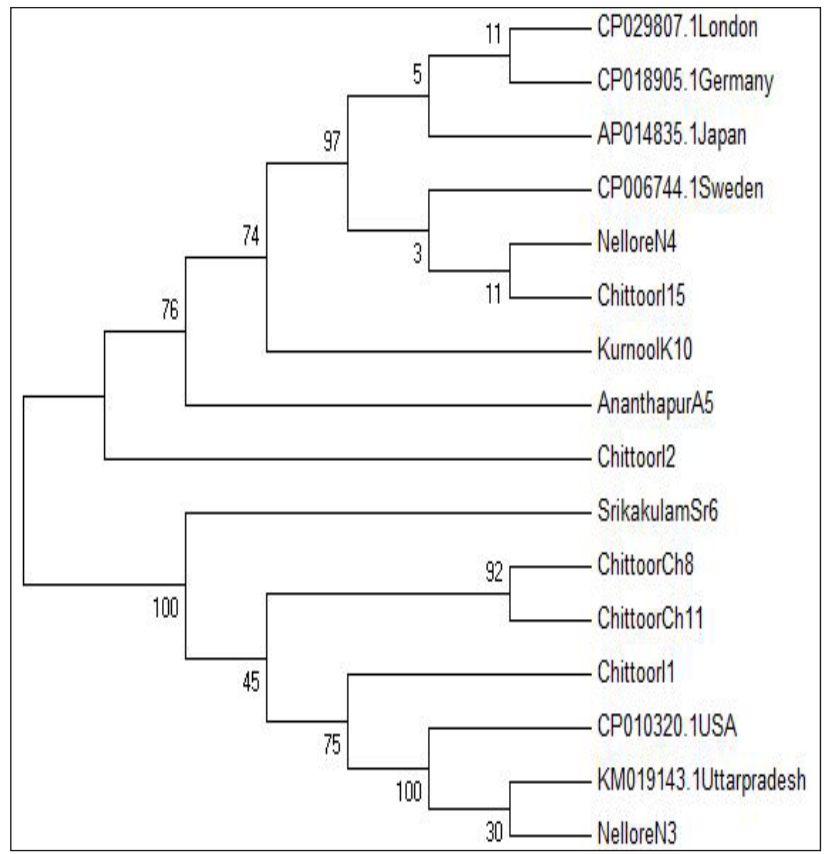

Fig. 5: Phylogenetic analysis of $C A P$ gene (earpiece isolates) of Bacillus anthracis - Andhra Pradesh

The Phylogenetic analysis of species specific rpoB gene of earpiece isolates of NelloreN3 isolate showed close relationship with Japan strain (Accession No: AP014833). Ch8, Sr6, rA5, K12 isolates formed separate clusters with Brazil strain (Accession No:CP019588), Germany strain (Accession No: CP018903), London strain (Accession No: CP029805), USA strain (Accession No: CP012730), Japan strain (Accession No: AP014833) China strain (Accession No: CP031642). N3, Ch8, Sr6, A5, K12 isolates formed separate clusters with Uttar Pradesh strain (Accession 
No: JQ798178), West Bengal strain (KT831967) and Maharashtra strain (Accession No: JN572676) (Fig. 6).

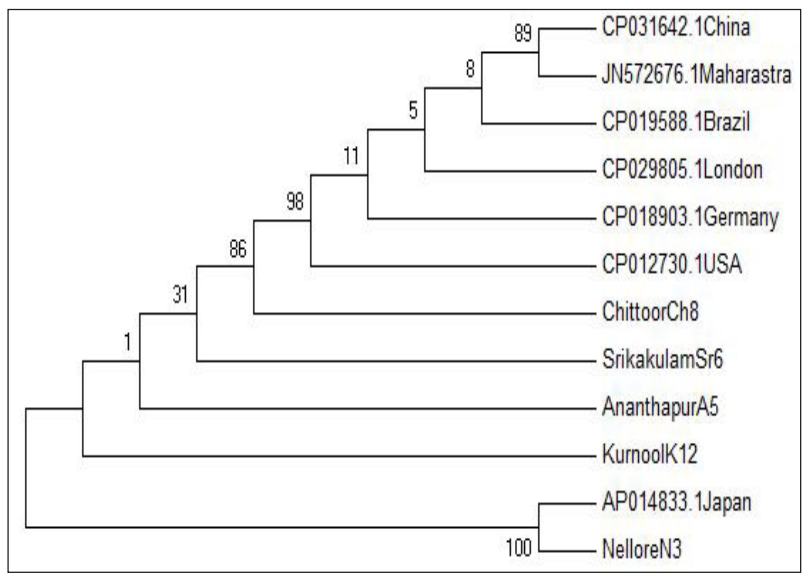

Fig. 6: Phylogenetic analysis of $r p o B$ gene (earpiece isolates) of Bacillus anthracis-Andhra Pradesh

Similarly, the phylogenetic analysis of species specific $r p o B$ gene of soil isolates, AS30, SJ6, KN18, VV25 formed separate clusters with Brazil strain (Accession No: CP019588), Germany strain (Accession No: CP018903), London strain (Accession No: CP029805), USA strain (Accession No: CP012730), Japan strain (Accession No: AP014833) China strain (Accession No: CP031642). AS30, SJ6, KN18, VV25 isolates formed separate clusters Uttar Pradesh strain (Accession No: JQ798178), West Bengal strain (KT831967) and Maharashtra strain (Accession No: JN572676). Whereas, AS30, SJ6 isolates showed close relationship with KN18; VV25 isolates respectively (Fig. 7).

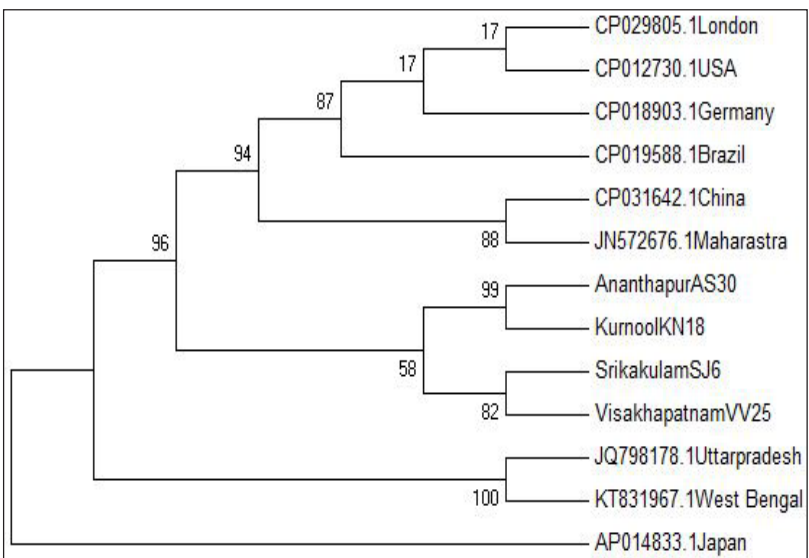

Fig. 7: Phylogenetic analysis of $r p o B$ gene (soil isolates) of Bacillus anthracis-Andhra Pradesh
Results of Phylogenetic analysis of chromosomal Bacillus anthracis isolates recovered from clinical earpiece and environmental soil samples

The Phylogenetic analysis of chromosomal Ba813 gene of earpiece isolates, K12, I2, I15, Ch11 formed separate clusters with Japan strain (Accession No: AP014833). N3, K10, I14, I1, Sr6 formed separate clusters with London strain (Accession No: CP029805), China strain (Accession No:CP031642), Brazil strain (Accession No: CP019588), Germany strain (Accession No: CP018903). But N4, A5, A13 isolates showed close relationship with N7, Ch8, I9 respectively. The isolates K12, I2, I15, Ch11 formed separate clusters with A5, Ch8, A13, I9 isolates. Whereas N3, K10, I14, I1, Sr6 formed separate clusters with N4, N7 (Fig. 8).

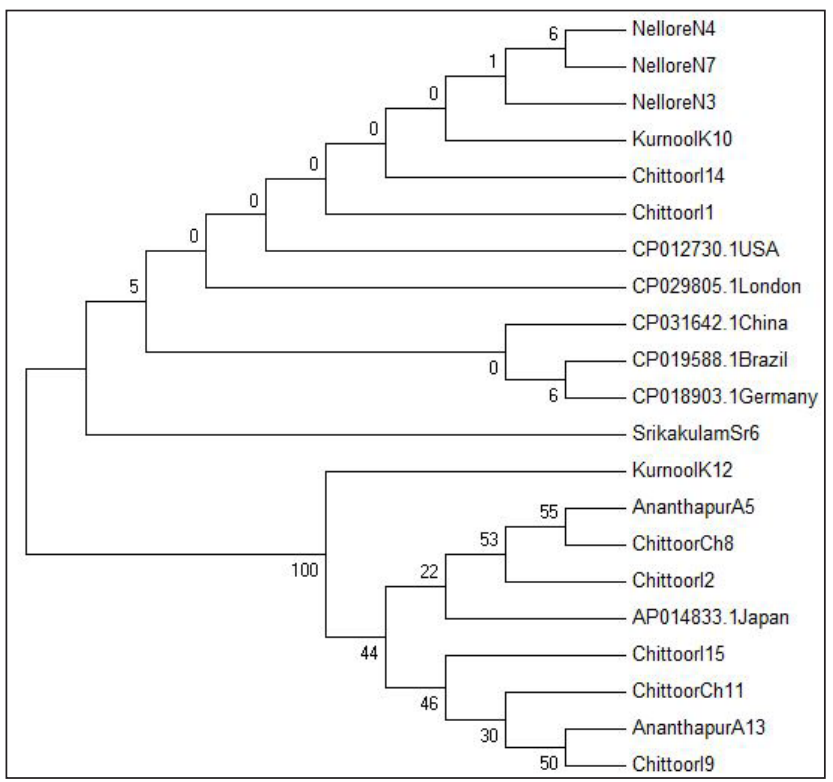

Fig. 8: Phylogenetic analysis of chromosomal Ba813 gene (earpiece isolates) of Bacillus anthracis-Andhra Pradesh

Similarly, the phylogenetic analysis of Chromosomal Ba813 gene of soil isolates of VM9 showed close relationship with Japan strain (Accession No: AP014833). AS33, KN19, VM7, AS31 formed separate clusters with Japan strain (Accession No: AP014833). 1KN21, VG4, VP11 formed separate clusters with USA strain (Accession No: CP012730), London strain (Accession No:CP029805), Germany strain (Accession No:CP018903),Brazil strain (Accession No:CP019588), China strain (Accession No:CP031642). AS28, VP12, AS30, AS38 isolates showed 
close relationship with KN18, VV25, AS42, SJ6 isolates respectively. AS33, KN19, VM7, AS31 formed separate clusters with VM9, AS30, AS42, AS38, and SJ6 isolates. 1KN21, VG4, VP11 formed separate clusters with AS28, 1KN18, VP12, VV25 (Fig. 9).

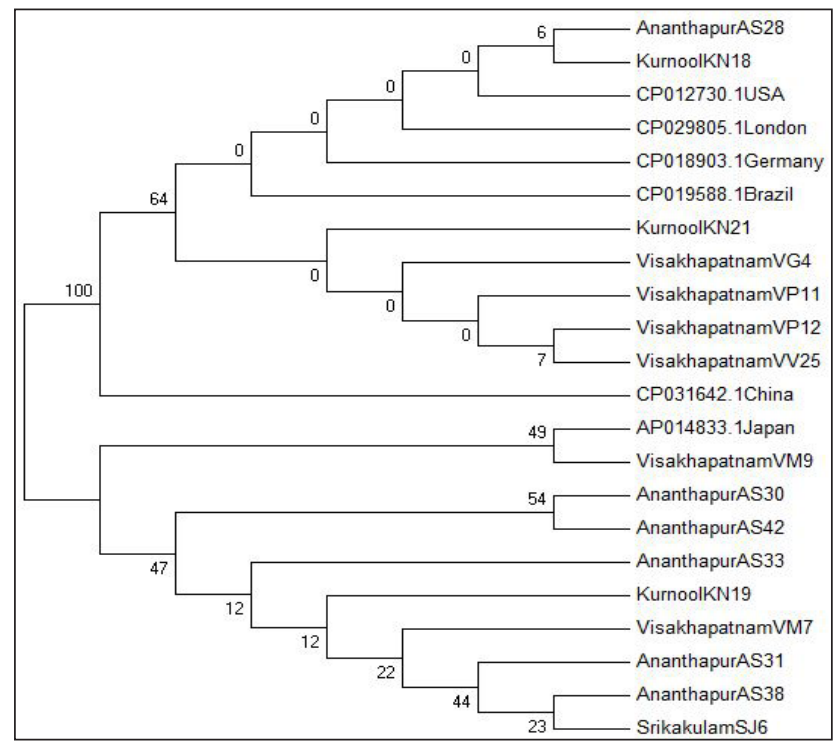

Fig. 9: Phylogenetic analysis of chromosomal Ba813 gene (soil isolates) of Bacillus anthracis - Andhra Pradesh

On Phylogenetic analysis, genus specific rpoB gene of Sr6 earpiece and SJ6 soil isolates showed close relationship with reference strain of USA(Accession No: CP012730) and VV25 soil isolate respectively. Phylogenetic analysis of species specific PA gene of I9, I11, Ch8, K10 earpiece isolates showed close relationship with Ch11, I15,N7 and Sr6 earpiece isolates respectively whereas AS30, KN19 soil isolates showed close relation with KN19 and VV25 respectively. Phylogenetic analysis of chromosomal Ba813 gene of N4, A5, and A13 isolates are closely related to N7, Ch8 and I9 earpiece isolates respectively whereas AS30, AS31, AS42 soil isolates are closely related to KN18, VV25 and SJ6 soil isolates respectively. The results of phylogenetic analysis of all the genes of remaining isolates formed separate clusters with respective reference strains of genbank.

During the study, all the 31 isolates earpiece (15) and soil (16) were positive for bacillus genus with genus specific primers on PCR.Out of 15 earpiece isolates, only 13 isolates for plasmid encoding $P A$ gene and 10 isolates for $C A P$ gene were positive on PCR confirming these isolates were B.anthracis. However,none of the isolates from soil were positive for $C A P$ gene, but only 9 isolates of 16 soil isolates were positive for $P A$ gene confirming $B$. anthracis. But all the 31 (earpiece-15, soil-16) were confirmed as $B$. anthracis with species specific rpoB and chromosomal Ba813 genes.

Identification of B.anthracis by PCR targeting only toxin encoding genes (pXO1 or pXO2) may not accurately identify the $B$. anthracis, because of the transfer of plasmid by horizontal gene transfer among closely related species (Kwan et al., 2003). All the B. anthracis isolates may not contain the toxin encoding genes and there is a chance of natural loss of plasmids (Ko et al., 2003; Vahedi et al., 2009). Hence, in the present study, combination of B.anthracis specific chromosomal markers(chromosomal Ba813 and rро $B$ ) along with toxin encoding genes $(P A$ of $\mathrm{pXO} 1$ and $C A P$ gene of $\mathrm{PXO} 2)$ targeting PCR's were performed for specific identification of B.anthracis. A total of 81 PCR amplicons targeting (Table 2) genus specific rpoB gene (9); species specific genes, $P A$ gene of pXO1 (22),CAP gene of pXO2(10), rроB gene(9) and chromosomal Ba813 gene (31) from outbreak/endemic areas were sent to Genei Pvt, Ltd., Bangalore for sequencing. The sequences received were analyzed through NCBI blast tool to compare nucleotide percentage identity and ancestral relatedness of isolates with references sequences available in the gene bank database.

Table 2: Number of PCR amplicons sent for sequencing

\begin{tabular}{|c|c|c|c|c|c|}
\hline $\begin{array}{l}\text { Sl. } \\
\text { No. }\end{array}$ & Targeting genes & & Earpiece & Soil & Total \\
\hline \multirow[t]{2}{*}{1} & $\begin{array}{l}\text { Genus specific } \\
\text { gene }\end{array}$ & $\begin{array}{l}\text { rpoB gene for } \\
\text { Bacillus }\end{array}$ & 5 & 4 & 9 \\
\hline & & $P A$ gene of $\mathrm{pXO} 1$ & 13 & 9 & 22 \\
\hline \multirow{2}{*}{2} & Species specific & $C A P$ gene of $\mathrm{pXO} 2$ & 10 & 0 & 10 \\
\hline & genes & $\begin{array}{l}\text { rpoB gene of } \\
\text { B.anthracis }\end{array}$ & 5 & 4 & 9 \\
\hline \multirow[t]{2}{*}{3} & $\begin{array}{l}\text { Chromosomal } \\
\text { specific gene }\end{array}$ & Ba813 gene & 15 & 16 & 31 \\
\hline & Grand total & & 48 & 33 & 81 \\
\hline
\end{tabular}

In the present study, all the isolates of clinical earpiece and environmental soil were identified as bacillus and shown identity of $99-100 \%$ with reference sequences deposited in the gene bank whereas all the Bacillus anthracis isolates of clinical earpiece and environmental soil samples 
were shown $98-100 \%$ identity with gene bank reference sequences. Hence, the present molecular characterization studies revealed that $99 \%$ of the isolates yielded as Bacillus with genus specific primers and $98 \%$ of the isolates as $B$. anthracis with species specific primers.

Further, phylogenetic analysis of Bacillus anthracis isolates recovered from earpiece and soil in endemic regions of Andhra Pradesh shown close evolutionary relationship with each other but earpiece isolates of Srikakulam (Accession No: MK310254) and Nellore shared ancestral relation with global reference strains of USA (Accession No: CP012730) and Japan(Accession no: AP014833) respectively. Similarly soil isolate of Visakhapatnam also shared ancestral relation with global reference strain of Japan (Accession no: AP014833). This phylogenetic analysis deciphered that there is no strain variation among isolates of B.anthracis identified in endemic regions from different districts of Andhra Pradesh.

\section{CONCLUSION}

The study revealed that $B$. anthracis from all the endemic districts of Andhra Pradesh are capable of producing fresh outbreaks even though they lack genes encoding major virulence producing Plasmids. However, nature of $B$. anthracis has to be studied further to know its changing mechanisms in producing fresh out breaks at intervals even after annual vaccinations at endemic areas of Andhra Pradesh.

\section{ACKNOWLEDGMENTS}

The authors are highly thankful to Sri Venkateswara Veterinary University, Tirupati Andhra Pradesh in providing necessary facilities/funding to carry out this work.

\section{REFERENCES}

Akiko, O., Satoshi I. and Shigeru M. 2019. Comparative genomics and phylogenetic analysis of Bacillus anthracis strains isolated from domestic animals in Japan. Infect Genet Evol., 71: 128-139.

Akanxa, R., Saugata M., Joseph, J.K. and Manmohan Parida. 2020. Molecular characterization of Bacillus anthracis isolates from the anthrax outbreak among cattle in Karnataka, India. BMC Microbiol., 20: 232.

Helgason, E., Caugant, D.A., Olsen, I. and KolstØ, A.B. 2000. Genetic structure of population of Bacillus cereus and $B$. thuringiensis isolates associated with periodontitis and other human infections. J. Clin. Microbiol., 38: 1615-1622.

Kwan, S.K., Kim, J.M., Kim, J.M., Jung, B.Y., Kim, W., Jung Kim, I.K. and Kook, Y.H. 2003. Identification of Bacillus anthracis by rpoB Sequence Analysis and Multiplex PCR. $J$ Clin. Microbiol., 41(7): 2908-2914.

Keim, P., Pearson, T. and Okinaka, R.T. 2008. Evolution of Bacillus anthracis, causative agent of anthrax. Evol. Biol Bact. Fung. Patho., pp. 523-33.

Maughan, H. and Vander, A.G. 2011. Bacillus taxonomy in the genomic era finds phenotypes to be essential though often misleading. Infect. Genet. Evol., 11(5): 789-797.

Pannucci, J., Okinaka, R.T., Sabin, R. and Kuske, C.R. 2002. Bacillus anthracis pXO1 plasmid sequence conservation among closely related bacterial species. J. Bacteriol., 184: 134-141.

Thwaite, J.E., Baillie, L.W.J., Carter, N.M., Stephenson, K., Rees, M., Harwood, C.R., and Emmerson, P.T. 2002. Optimization of the cell wall micro-environment allows increased production of recombinant Bacillus anthracis protective antigen from B. subtilis. Appl. Environ. Microbiol., 68 (1): 227-234.

Tamura, K., Stecher, G., Peterson, Daniel., Filipski, A. and Sudhir Kumar. 2013. MEGA6: Molecular Evolutionary Genetics Analysis Version 6.0. Mol. Biol. Evol., 30(12): $2725-2729$.

Vahedi, F., Jula, G.M., Kianizadeh, M. and Mahmoudi, M. 2009. Characterization of Bacillus anthracis spores isolates from soil by biochemical and multiplex PCR analysis. E Mediterr. Health J., 15:149-156. 